DOI

\title{
ПОРУШЕННЯ ПОКАЗНИКІВ ГУМОРАЛЬНОГО ІМУНІТЕТУ ТА ВМІСТУ ЦИРКУЛЮЮЧИХ ІМУННИХ КОМПЛЕКСІВ В ДИНАМІЦІ РАННЬОГО ПЕРІОДУ ПІСЛЯ НАНЕСЕННЯ СКЕЛЕТНОї, ЧЕРЕПНО-МОЗКОВОї ТА ПОЄДНАНОї ТРАВМ
}

\author{
ОР. Д. Левчук
}

ДВНЗ «Тернопільський державний медичний університет імені І. Я. Горбачевського мОз України»

РЕЗЮМЕ. У ранній період після нанесення скелетної, черепно-мозкової та поєднаної травм (1-7 доби), порівняно із контрольною групою, в сироватці крові суттєво зростає вміст Ig A, G, циркулюючих імунних комплексів. Через 3 доби показники досягають максимуму й залишаються на такому ж рівні до 7 доби. Вміст у сироватці крові Ig А та циркулюючих імунних комплексів істотно більший після поєднаної травми через 7 діб посттравматичного періоду. Через 3-7 діб після нанесення травм у сироватці крові суттєво знижується вміст Ig М. Динаміка вмісту Ig $\mathrm{G}$ та М не залежить від локалізації механічних травм.

КЛЮчОВІ СлОВА: скелетна, черепно-мозкова, поєднана травма, імуноглобуліни, циркулюючі імунні комплекси.

Вступ. Травматизм $\epsilon$ актуальною проблемою сьогодення. В його структурі провідне місце займає поєднана травма, яка характеризується розвитком синдрому системної відповіді на запалення, що нерідко ускладнюється поліорганною дисфункцією і недостатністю [11]. Останніми роками зростає частка поєднаної краніоскелетної травми, яка належить до головних причин смертності та інвалідизації населення [2].

Важливе місце в патогенезі травматичної хвороби, яка розвивається при дії механічної травми значної сили, належить імунологічним порушенням. В основі їх патогенезу провідну роль відіграють прозапальні медіатори, які розповсюджуються з током крові від місця безпосередньої травми і стимулюють апоптоз імунокомпетентних клітин із розвитком вторинного імунодефіциту [1]. Серед сукупності патологічних змін в умовах тяжкої травми важливе місце відводиться накопиченню циркулюючих імунних комплексів (ЦІК) у сироватці крові. У ряді робіт показано, що в умовах експериментальної політравми вміст ЦІК підвищений протягом тривалого часу $[4,5]$. Характерною рисою впливу підвищеного вмісту ЦІК $\epsilon$ їх нагромадження у тканинах із розвитком аутоімунних реакцій, посиленням агрегації та адгезії тромбоцитів у судинах, що призводить до облітерації судин гемомікроциркуляторного русла, порушення мікроциркуляції та пошкодження і некрозу тканин [3]. Однак роль різних за локалізацією механічних травм (скелетної, черепно-мозкової та поєднаної) в патогенезі порушень імунітету та накопичення ЦІК в ранній період травматичної хвороби вивчений недостатньо, що обмежує розуміння закономірностей розвитку імунологічних порушень в умовах краніоскелетної травми.
Мета роботи - з'ясувати закономірності порушень показників гуморального імунітету та вмісту циркулюючих імунних комплексів в динаміці раннього періоду після скелетної, черепномозкової та поєднаної травм.

Матеріал і методи дослідження. Експерименти виконано на 104 нелінійних білих щурах масою 180-200 г, яких утримували на стандартному раціоні віварію. Нанесення травм виконували в умовах тіопентало-натрієвого наркозу (40 мг·к $\Gamma^{1}$ маси). Моделювання поєднаної краніоскелетної травми виконували за розробленою нами методикою шляхом дозованого удару по обох задніх лапах за допомогою спеціально розробленого пристрою, який викликав закритий перелом обох стегон, та нанесення дозованого удару по черепу з енергією 0,375 Дж, що відповідало травмі середнього ступеня тяжкості [10]. В окремих групах ці травми наносили окремо. Контрольну групу склали інтактні тварини.

Тварин, що вижили, виводили з експерименту в умовах знеболювання через 1, 3 і 7 діб посттравматичного періоду шляхом тотального кровопускання з серця. Для дослідження використовували сироватку крові, в якій імуноферментним методом визначали вміст імуноглобулінів основних класів A, M і G з використанням аналізатора Stat Fax (USA) та ЦІК методом преципітації розчином поліетиленгліколю 6000 [9].

Отримані цифрові дані піддавали статистичному аналізу. Достовірність відмінностей між експериментальними групами оцінювали з використанням програми STATISTICA 10.0 ("StatSoft, Inc.", США).

Результати й обговорення. Дослідження показали, що в умовах моделювання механічних травм різної локалізації розвивалися порушення 
Огляди літератури, оригінальні дослідження, погляд на проблему

показників гуморального імунітету. Так, порівняно із контрольною групою, в сироватці крові спостерігалося істотне збільшення Ig A (табл. 1): після самої скелетної травми через 1 добу - на $53,9 \%(p<0,05)$, через 3 доби - на 54,8 \% ( $<<0,05)$, через 7 діб - на 56,7 \% ( $<<0,05)$; після черепномозкової-відповідно на 53,9, 76,3 і 74,4\% ( $p<0,05)$, після поєднаної - відповідно на 62,0, 94,3 і 94,5 \% ( $<<0,05)$. Порівнюючи дослідні групи між собою, було встановлено, що через 1 добу не відмічалося істотних відмінностей за величиною вмісту в сироватці крові Ig A на тлі механічних травм різної локалізації ( $p>0,05)$. Через 3 доби показник виявився істотно більшим після нанесення черепно-мозкової і поєднаної травм, порівняно із скелетною (відповідно на 13,9 і 25,6 \%, p<0,05). Через 7 діб показник явно ставав більшим після поєднаної травми: на 24,1 \% порівняно із самою скелетною травмою $(p<0,05)$ і на 11,5 \% - порівняно із черепно-мозковою травмою $(p<0,05)$. Аналіз динаміки досліджуваного показника виявив, що після самої скелетної травми показник вже через 1 добу досягав максимальної величини й залишався на такому ж рівні до 7 доби $(p>0,05)$. Після моделювання черепно-мозкової травми показник досягав максимуму через 3 доби, що виявилося істотно більшим, ніж через 1 добу (на 15,6 \%, $\mathrm{p}<0,05)$ й залишався на такому ж рівні до 7 доби (p>0,05). Аналогічно збільшувався вміст Ig А у сироватці крові після нанесення поєднаної травми: через 3 доби показник досягав максимальної величини, був на 19,9 \% більшим, ніж через 1 добу $(p<0,05)$, й в подальшому до 7 доби не змінювався $(p>0,05)$.

Таблиця 1. Вміст імуноглобулінів А, М, G та ЦІК у сироватці крові в динаміці раннього періоду скелетної, черепномозкової та поєднаної травм $(\mathrm{M} \pm \mathrm{m})$

\begin{tabular}{|c|c|c|c|c|}
\hline Вид травми & Контроль & 1 доба & 3 доба & 7 доба \\
\hline \multicolumn{5}{|l|}{$\lg A, \Gamma \cdot \Omega^{-1}$} \\
\hline скелетна & \multirow{3}{*}{$1,063 \pm 0,044$} & $\begin{array}{l}1,693 \pm 0,055^{*} \\
(n=10)\end{array}$ & $\begin{array}{l}1,645 \pm 0,051 * \\
(n=10)\end{array}$ & $\begin{array}{l}1,666 \pm 0,062 * \\
(n=9)\end{array}$ \\
\hline черепно-мозкова & & $\begin{array}{l}1,617 \pm 0,045^{*} \\
(n=10)\end{array}$ & $\begin{array}{l}1,874 \pm 0,069 * 1 \\
(n=8)\end{array}$ & $\begin{array}{l}1,854 \pm 0,088^{*} \\
(n=7)\end{array}$ \\
\hline поєднана & & $\begin{array}{l}1,723 \pm 0,057^{*} \\
(n=8)\end{array}$ & $\begin{array}{l}2,066 \pm 0,085 * 1 \\
(n=7)\end{array}$ & $\begin{array}{l}2,067 \pm 0,031 * 1,2 \\
(n=7)\end{array}$ \\
\hline \multicolumn{5}{|l|}{$\lg M, \Gamma \cdot \pi^{-1}$} \\
\hline скелетна & \multirow{3}{*}{$1,683 \pm 0,060$} & $\begin{array}{l}1,867 \pm 0,067 \\
(n=10)\end{array}$ & $\begin{array}{l}1,405 \pm 0,039 * \\
(n=10)\end{array}$ & $\begin{array}{l}1,468 \pm 0,033^{*} \\
(n=9)\end{array}$ \\
\hline черепно-мозкова & & $\begin{array}{l}1,673 \pm 0,047^{1} \\
(n=10)\end{array}$ & $\begin{array}{l}1,400 \pm 0,051 * \\
(n=8)\end{array}$ & $\begin{array}{l}1,443 \pm 0,042 * \\
(n=7)\end{array}$ \\
\hline поєднана & & $\begin{array}{l}1,857 \pm 0,071 \\
(n=8)\end{array}$ & $\begin{array}{l}1,470 \pm 0,058^{*} \\
(n=7)\end{array}$ & $\begin{array}{l}1,391 \pm 0,037^{*} \\
(n=7)\end{array}$ \\
\hline \multicolumn{5}{|l|}{$\lg G, \Gamma \cdot \pi^{-1}$} \\
\hline скелетна & \multirow{3}{*}{$4,823 \pm 0,092$} & $\begin{array}{l}5,333 \pm 0,128 * \\
(n=10)\end{array}$ & $\begin{array}{l}5,824 \pm 0,091 * \\
(n=10)\end{array}$ & $\begin{array}{l}5,794 \pm 0,140 * \\
(n=9)\end{array}$ \\
\hline черепно-мозкова & & $\begin{array}{l}4,833 \pm 0,113^{1} \\
(n=10)\end{array}$ & $\begin{array}{l}5,838 \pm 0,184^{*} \\
(n=8)\end{array}$ & $\begin{array}{l}5,941 \pm 0,191 * \\
(n=7)\end{array}$ \\
\hline поєднана & & $\begin{array}{l}5,813 \pm 0,184^{* 2} \\
(n=8)\end{array}$ & $\begin{array}{l}5,981 \pm 0,141 * \\
(n=7)\end{array}$ & $\begin{array}{l}5,780 \pm 0,178^{*} \\
(n=7)\end{array}$ \\
\hline \multicolumn{5}{|l|}{ ЦІК, ум.од. } \\
\hline скелетна & \multirow{3}{*}{$59,50 \pm 2,56$} & $\begin{array}{l}116,2 \pm 4,0 * \\
(n=10)\end{array}$ & $\begin{array}{l}140,3 \pm 4,5^{*} \\
(n=10)\end{array}$ & $\begin{array}{l}162,3 \pm 3,4^{*} \\
(n=9)\end{array}$ \\
\hline черепно-мозкова & & $\begin{array}{l}105,0 \pm 4,0 * \\
(n=10)\end{array}$ & $\begin{array}{l}157,6 \pm 6,6^{*} \\
(n=8)\end{array}$ & $\begin{array}{l}172,3 \pm 4,5^{*} \\
(n=7)\end{array}$ \\
\hline поєднана & & $\begin{array}{l}129,0 \pm 4,7^{* 2} \\
(n=8)\end{array}$ & $\begin{array}{l}173,9 \pm 4,9 * 1 \\
(n=7)\end{array}$ & $\begin{array}{l}197,6 \pm 3,6 * 1,2 \\
(n=7)\end{array}$ \\
\hline
\end{tabular}

Примітки:

1. * - відмінності стосовно контрольної групи статистично вірогідні $(\mathrm{p}<0,05)$;

2. ${ }^{1}$ - відмінності стосовно групи із скелетною травмою статистично вірогідні $(p<0,05)$;

$3^{2}{ }^{2}$ - відмінності стосовно групи із черепно-мозковою травмою статистично вірогідні $(p<0,05)$.

У свою чергу вміст у сироватці крові Ig M (табл. 1) через 1 добу практично не відрізнявся від рівня контролю при всіх модельованих травмах
( $p>0,05)$. Через 3 доби його величина статистично вірогідно знижувалася, порівняно із контролем: після скелетної травми - на 16,5 \% (p<0,05), після 
Огляди літератури, оригінальні дослідження, погляд на проблему

черепно-мозкової - на 16,8 \% $(p<0,05)$ після поєднаної травми - на $12,7 \%(p<0,05)$, що виявилося також статистично вірогідно меншим, ніж через 1 добу $(p<0,05)$. Через 7 діб показник залишався на рівні 3 доби при всіх модельованих травмах ( $>0,05)$. Порівнюючи дослідні групи між собою ми з'ясували, що через 1 добу показник був істотно більшим на тлі самої скелетної травми, порівняно із черепно-мозковою (на 11,6 \%, р<0,05). В інші терміни спостереження показник істотно не відрізнявся між групами порівняння $\left(p_{2}>0,05\right)$.

Bміст Ig G в сироватці крові під впливом модельованих травм збільшувався, порівняно із контролем (табл. 1). Через 1 добу статистично значущі відмінності спостерігалися після нанесення скелетної і поєднаної травм (відповідно на 10,6 і 20,5 \%, p<0,05). Через 3 доби показник ставав більшим від рівня контролю на тлі всіх модельованих травм: скелетної на 20,8 \%, черепномозкової - на 21,0 \%, поєднаної - на 24,0 \% $(p<0,05)$. Через 7 діб показник залишався на такому ж рівні, порівняно із 3 добою і був суттєво вищим, ніж у контролі - відповідно на 20,1, 19,8 і 23,2\% (p<0,05). Порівнюючи дослідні групи між собою ми з'ясували, що через 1 добу вміст у сироватці крові Ig G був більшим на тлі скелетної і поєднаної травм, порівняно із черепно-мозковою (відповідно на 10,3 \%, $\mathrm{p}_{2}<0,05$ і на 20,3\%, p<0,05). В інші терміни спостереження - окремо через 3 i 7 діб посттравматичного періоду величина вмісту Ig G в сироватці крові на тлі модельованих травм була практично однаковою $\left(p_{2}>0,05\right)$.

Моделювання різних за локалізацією скелетних травм супроводжувалося суттєвим зростанням Вмісту ЦІК у сироватці крові порівняно із контрольною групою (табл. 1). Після скелетної травми показник через 1 добу збільшувався на $95,3 \%$ ( $p<0,05)$, через 3 доби - у 2,51 раза ( $p<0,05)$, через 7 діб - у 2,72 раза $(p<0,05)$; після черепномозкової - відповідно на 76,5 \% та у 2,65 і 2,90 раза ( $<<0,05)$; після поєднаної - відповідно у 2,17, 2,92 і 3,32 раза $(p<0,05)$. Порівнюючи дослідні групи між собою ми з'ясували, що через 1 добу показник був істотно більшим після поєднаної травми, порівняно із черепно-мозковою (на 22,9\%, p<0,05). Через 3 доби вміст ЦІК у сироватці крові на тлі поєднаної травми суттєво перевищував аналогічний після нанесення скелетної травми (на 23,9\%, р<0,05). Через 7 діб показник знову виявився найбільшим після поєднаної травми та статистично вірогідно відрізнявся від скелетної (на 21,7 \%, р<0,05) та черепномозкової (на 14,7 \%, p<0,05). Аналіз динаміки досліджуваного показника виявив, що через 3 доби на тлі всіх модельованих травм вміст у сироватці крові ЦІК ставав істотно більшим: після скелетної на 20,7 \% (p<0,05), після черепно-мозкової - на 50,1\%
( $p<0,05)$, після поєднаної - на 34,8\% (p<0,05). Через 7 діб після нанесення скелетної і черепно-мозкової травм показник залишався на рівні 3 доби (р>0,05), тоді як після поєднаної травми - зростав і ставав на $13,6 \%$ більшим ( $p<0,05)$.

Отримані результати свідчать про те, що модельовані травми супроводжуються вираженими порушеннями гуморального імунітету. Так, вміст у сироватці крові Ig А під впливом модельованих травм в усі терміни спостереження був суттєво більшим, ніж у контрольній групі. Найбільші порушення через 3 доби виникали після черепномозкової і поєднаної травм, через 7 діб - після поєднаної травми. Ці дані вказують на істотне ураження слизових оболонок, насамперед легень і шлунково-кишкового тракту [7], що може призвести до гострого респіраторного дистрессиндрому та розвитку ентеральної дисфункції.

У свою чергу вміст у сироватці крові Ig М через 1 добу посттравматичного періоду залишався на рівні контрольної групи, проте через 3-7 діб ставав меншим, ніж у контролі. В цих умовах його динаміка не залежала від локалізації скелетної травми. Ці дані вказують на формування під впливом модельованих травм вторинного імунодефіциту, що може стати причиною розвитку гнійносептичних ускладнень [6].

Вміст у сироватці крові Ig G після нанесення різних за локалізацією скелетних травм збільшувався, порівняно із контрольною групою, досягаючи максимальної величин через 3 доби посттравматичного періоду. Через 7 діб показник залишався на рівні попереднього терміну спостереження і був практично однаковим в усіх дослідних групах. Його збільшення, очевидно, пов'язане із виходом лімфоцитів із кров'яних депо і $є$ типовою реакцією гуморального імунітету у ранній період після моделювання тяжкої механічної травми [4].

Збільшення антигенного навантаження організму, посилене утворення імуноглобулінів супроводжується накопиченням у сироватці крові імунних комплексів, вміст яких досягає максимуму через 3-7 діб після нанесення травми. Це може супроводжуватися поглибленням порушень мікроциркуляції, гіпоксії, а також стимулювати розвиток аутоімунних процесів, що поглиблює перебіг основної патології [8].

Таким чином, у ранній період після нанесення скелетної, черепно-мозкової та поєднаної травм має місце порушення гуморальної ланки імунітету, що супроводжується збільшенням вмісту в сироватці крові Ig A та G, а також зниженням вмісту lg M. У цих умовах вже з першої доби після моделювання травм зростає вміст ЦІК. Максимум порушень настає через 3-7 діб і є більшим після поєднаної травми, що слід враховувати у комплексній інтенсивній терапії. 
Огляди літератури, оригінальні дослідження, погляд на проблему

Висновки. 1. У ранній період після нанесення скелетної, черепно-мозкової та поєднаної травм (1-7 доби) в порівнянні із контрольною групою в сироватці крові суттєво зростає вміст Ig A та G. Через 3 доби показники досягають максимуму й залишаються на такому ж рівні до 7 доби. Вміст у сироватці крові Iو A істотно більший після поєднаної травми через 7 діб посттравматичного періоду, тоді як динаміка вмісту Ig G не залежить від локалізації механічної травми.

2. Вміст у сироватці крові Ig М після модельованих травм через 3-7 діб стає статистично вірогідно меншим, ніж у контролі. В ці терміни не відмічалося істотних відмінностей величини до-

\section{ЛІТЕРАТУРА}

1. Дзюба Д. А. Показатели активации апоптоза в течении политравмы тяжелой степени / Д. А. Дзюба, И. Р. Малыш, Л. В. Згржебловская // Український журнал екстремальної медицини імені Г. О. Можаєва. - 2008. Т. 9, № 1. - С. 53-58.

2. Ельский В.Н. Моделирование черепно-мозговой травмы / В. Н. Ельский, С. В. Зяблицев. - Донецк : Издво “Новый мир", 2008. - 140 с.

3. Казмірчук В. $€$. Клінічна імунологія і алергологія / В. Є. Казмірчук, Л. В. Ковальчук. - Вінниця : Нова книга. - 2006. - С. 267-275.

4. Козак Д. В. Динаміка вмісту циркулюючих імунних комплексів та імуноглобулінів у відповідь на політравму в експерименті / Д. В. Козак // Клінічна хірургія. - 2013. - № 12 (852). - С. 76-78.

5. Козак Д. В. Вплив карбацетаму на динаміку показників цитолізу та вміст циркулюючих імунних комплексів в умовах політравми / Д. В. Козак // Вісник наукових досліджень. - 2014. - № 2 (75). - С. 80-82.

6. Динамика концентраций иммуноглобулинов классов М, G, А в сыворотке крови у пациентов с бронхолегочными осложнениями в остром и раннем периодах позвоночно-спинномозговой травмы / Е. А. Конюченко, В. Ю. Ульянов, Д. М. Пучиньян, Е. В. Карякина // Саратовский научно-медицинский журнал. - 2010. - Т. 6, № 4. - С. 841-844. сліджуваного показника в залежності від локалізації скелетної травми.

3. Моделювання скелетної, черепно-мозкової і поєднаної травм супроводжується суттєвим збільшенням вмісту в сироватці крові ЦІК, порівняно із контрольною групою, впродовж 1-7 діб спостереження. У всі терміни спостереження показник найбільший після поєднаної травми, через 7 діб він істотно зростає й після черепно-мозкової.

Перспективи подальших досліджень. У перспективі передбачається вивчення стану гуморальної ланки імунітету в період пізніх проявів травматичної хвороби після нанесення скелетної, черепномозкової і поєднаної травм та розробка засобів корекції імунних порушень.

7. Малыш И. Р. Характеристика изменений в клеточном и гуморальном иммунитете у пострадавших с синдромом полиорганной недостаточности вследствие тяжелой политравмы / И. Р. Малыш // Український медичний альманах. - 2005. - Т. 8, № 5. С. 98-101.

8. Марченко М. І. Циркулюючі імунні комплекси в діагностиці аутоімунних захворювань / М. І. Марченко // Студентський нуковий журнал. - 2008. - режим доступу : http://s-journal.cdu.edu.ua/base/2008/v2/ v2pp109-110.pdf

9. Оценка влияния факторов окружающей стреды на иммунологическую реактивность организма : методические рекомендации / НИИ общей и коммунальной гигиены им. А. Н. Марзеева. - К., 1988. - 23 с.

10. Пат. 81107Україна, МПК G 09B 23/28. Спосіб моделювання політравми / Левчук Р. Д., Михайлюк І. А., Мерлєв Д. І. ; заявник і патентовласник Державний вищий навчальний заклад “Тернопільський державний медичний університет імені І. Я. Горбачевського МОЗ УКраїни". № u 201213575 ; заявл. 27.11.12 ; опубл. 25.06.13, Бюл. 12.

11. Рощін Г. Г. Багатофакторний аналіз летальності при поєднаній травмі органів черевної порожнини / Г. Г. Рощін, В. І. Іванов, В. О. Крилюк // Клінічна хірургія. - К. : ТОВ «Ліга-Інформ» - 2013. - № 4. - С. 40-44.

\title{
DISTURBANCE OF THE INDICATORS HUMORAL IMMUNITY AND CIRCULATING IMMUNE COMPLEXES IN THE DYNAMIC OF EARLY PERIOD AFTER SKELETAL, CRANIOCEREBRAL AND COMBINED TRAUMAS
}

OR. D. Levchuk

\author{
SHEI «Ternopil State Medical University by I. Ya. Horbachevsky of MPH of Ukraine»
}

SUMMARY. In the early period after application of skeleton, craniocerebra and combined traumas (1-7 days) in serum significantly increases the content of Ig A, G, circulating immune complexes compared to the control group. After 3 days this figure rises to a maximum and remains at the same level during 7 days. The content of Ig A and circulating immune complexes in serum significantly greater after the combined trauma after 7 days post-traumatic period. After 3-7 days after applying injuries in serum significantly reduced the content of $\mathrm{Ig}$ M. Dynamics of content changes of $\mathrm{Ig} \mathrm{G}$ and $M$ doesn't depend on the localization of mechanical traumas.

KEY WORDS: skeletal, craniocerebral, combined trauma, immunoglobulins, circulating immune complexes. 